\title{
Flow Control of Proton Exchange Membrane Fuel Cell with Theory of Inventive Problem Solving (TRIZ)
}

\author{
Chih-Ying Chuang, ${ }_{1}^{1}$ Chun-Hsiung Lan, ${ }^{2}$ Tian-Syung Lan, $3,4^{*}$ \\ Xuan-Jun Dai, ${ }^{3 * *}$ and Jian-Hua Qin ${ }^{3}$ \\ ${ }^{1}$ College of Electronic Information and Electrical Engineering, Huizhou University, \\ 46 Yanda Road, Huizhou, Guangdong 516007, China \\ ${ }^{2}$ Department of Business Administration, Hsing Wu University, New Taipei City 24452, Taiwan \\ ${ }^{3}$ College of Mechanical and Control Engineering, Guilin University of Technology, Guangxi 541004, China \\ ${ }^{4}$ Department of Information Management, Yu Da University of Science and Technology, \\ Miaoli County 36143, Taiwan
}

(Received October 21, 2020; accepted March 9, 2021)

Keywords: proton exchange membrane fuel cell, TRIZ, game theory, COMSOL

An optimization strategy is proposed to improve the performance of a proton exchange membrane fuel cell (PEMFC) by using the theory of inventive problem solving (TRIZ) and game theory. TRIZ is widely used to provide solutions to the problems of systematic and innovative designs as it is based on the analysis of scientific and engineering aspects in patented technologies. Factors that improve and worsen the flow control of air and hydrogen are selected by TRIZ. The selected factors are assessed to establish quality optimization strategies, with game theory used to formulate the reward matrix from the negotiation between two parameters. A COMSOL simulation of quality gain and loss was performed using the measured data of inlet temperature, inlet pressure, and pressure drop, which were found to be important factors. The results showed that the outlet temperature, outlet pressure, and pressure drop were improved by $16.67,78.8$, and $11.73 \%$ by the control of the inlet temperature, inlet pressure, and flow of air and hydrogen, respectively. TRIZ with game theory was proved effective for obtaining an appropriate flow control strategy of a PEMFC, and provides an effective and easy way to design and manufacture a device when there are many factors and parameters to consider.

\section{Introduction}

The development of society and technologies has been increasing energy demand, which requires alternative energy sources to prevent environmental problems from burning everincreasing amounts of fossil fuels. Hydrogen is regarded as an important alternative fuel as it is eco-friendly and has high energy density. Hydrogen is the main fuel of fuel cells that generate electricity through an electrochemical process involving hydrogen and oxygen. These fuel cells have a high energy conversion ratio with no emission of pollutants.

There are several types of fuel cells: alkaline fuel cells (AFCs), phosphoric acid fuel cells (PAFCs), molten carbonate fuel cells (MCFCs), solid oxide fuel cells (SOFCs), proton exchange

\footnotetext{
*Corresponding author: e-mail: tslan888@yahoo.com.tw

** Corresponding author: e-mail: daixuanjun@163.com

https://doi.org/10.18494/SAM.2021.3176
} 
membrane fuel cells (PEMFCs), and direct methanol fuel cells (DMFCs). Among them, PEMFCs are the most widely used owing to their compactness. However, it is still necessary to enhance their efficiency through improved control of the air and hydrogen flow and lowering the operating temperature. The flow control of water and hydrogen in PEMFCs affects the inlet/ outlet temperature and pressure, flow velocity, and pressure drop of air and hydrogen, which are related to humidification, drainage, and heat dissipation. Appropriate control reduces the flow resistance by improving the convection and diffusion of air and hydrogen through the electrode diffusion layers.

To establish an appropriate strategy of flow control, accurate measurement of related parameters is critical. For the measurement, various sensors are used in multichannel thermometers; electromagnetic flowmeters for air, hydrogen, and water; and electrochemical gas sensors in PEMFCs. Advanced sensing technologies allow precise and accurate measurements that provide the basic data of the required parameters for simulations of PEMFC operation, which lead to the establishment of an appropriate control strategy of flow control.

A strategy can be found with the appropriate data by the theory of inventive problem solving (TRIZ), which was first proposed by Altshuller. ${ }^{(1)}$ TRIZ was created to find different characteristics of problems and general patterns for inventive solutions through the analysis of patents with scientific and technological characteristics. Studies over the last few decades have confirmed that TRIZ is efficient and reliable in creative thinking and systematic innovative designs. TRIZ enhances the quality and efficiency of innovative inventions. TRIZ is applied in improving products and processes, eliminating process restrictions, forecasting technology, and developing new products. The benefits of TRIZ include the effective use of previous inventions, the enrichment of creative technology and invention technology, the reduction of cost and improvement of product quality, and so forth. León-Rovira and Aguayo showed that the relationship between the technical parameters of quality function deployment (QFD) can be solved by a contradiction matrix in TRIZ. ${ }^{(2)}$ Apte and Mann compared Taguchi's design method with TRIZ and suggested that better results are obtained by combining the two methods than by using each method separately. ${ }^{(3)}$

Engineering problems often have contradictions because a solution for a system can cause other problems that may worsen the system. Efficiency enhancement and design improvement of fuel cells also have such contradictions. TRIZ effectively solves the contradictions between two contradictory parameters with game theory. Starting from the relationship between parameters obtained by TRIZ, the optimal parameters that maximize the probability of increasing the efficiency need to be selected. This requires the application of game theory to the selection process to optimize the control of flows in a PEMFC.

In this study, we apply TRIZ with game theory to identify and analyze the problems of the flow control of air, hydrogen, and water in a PEFMC. The aim is to find an optimization strategy to improve the performance of a PEMFC by selecting the optimal parameters for flow control. The results provide a basis for the design and manufacture of flow channels in fuel cells to save time and resources when developing and manufacturing fuel cells. 


\section{Research Methods}

\subsection{Contradiction matrix}

The contradiction table of TRIZ in this study is a $39 \times 39$ matrix with the engineering factors in a PEMFC. ${ }^{(4)}$ The matrix provides a quick and simple method to find the principle of solving technical contradictions. ${ }^{(5)}$ The elements (cells) of the matrix indicate corresponding innovative principles of TRIZ $^{(6)}$ (Table 1).

Table 1

Thirty-nine factors in TRIZ in this study.

\begin{tabular}{|c|c|c|}
\hline No. & Factor & Explanation \\
\hline 1 & $\begin{array}{l}\text { Weight of moving } \\
\text { object }\end{array}$ & $\begin{array}{l}\text { The mass of an object in a gravitational field. The force that the body exerts on its support or } \\
\text { suspension. }\end{array}$ \\
\hline 2 & $\begin{array}{l}\text { Weight of a stationary } \\
\text { object }\end{array}$ & $\begin{array}{l}\text { The mass of an object in a gravitational field. The force that the body exerts on its support or } \\
\text { suspension, or on the surface on which it rests. }\end{array}$ \\
\hline 3 & $\begin{array}{l}\text { Length of a moving } \\
\text { object }\end{array}$ & Any linear dimension, not necessarily the longest, is considered as a length. \\
\hline 4 & $\begin{array}{l}\text { Length of a stationary } \\
\text { object }\end{array}$ & The same as 3 . \\
\hline 5 & $\begin{array}{l}\text { Area of a moving } \\
\text { object }\end{array}$ & $\begin{array}{l}\text { A geometrical characteristic is described by the part of a plane enclosed by a line, the part of } \\
\text { a surface occupied by an object, or the square measure of the internal or external surface of an } \\
\text { object. }\end{array}$ \\
\hline 6 & $\begin{array}{l}\text { Area of a stationary } \\
\text { object }\end{array}$ & The same as 5 . \\
\hline 7 & $\begin{array}{l}\text { Volume of a moving } \\
\text { object }\end{array}$ & $\begin{array}{l}\text { The cubic measure of space occupied by an object. Length } \times \text { width } \times \text { height for a rectangular } \\
\text { object, height } \times \text { area for a cylinder, etc. }\end{array}$ \\
\hline 8 & $\begin{array}{l}\text { Volume of a } \\
\text { stationary object }\end{array}$ & The same as 7 . \\
\hline 9 & Speed & The velocity of an object; the rate of a process or action in time. \\
\hline 10 & Force & $\begin{array}{l}\text { The force is a measure of the interaction between systems. In Newtonian physics, force }=\text { mass } \times \\
\text { acceleration. In TRIZ, the force is any interaction intended to change an object's condition. }\end{array}$ \\
\hline 11 & Stress or pressure & The force or tension per unit area. \\
\hline 12 & Shape & The external contours or the appearance of a system. \\
\hline 13 & $\begin{array}{l}\text { Stability of the } \\
\text { object's composition }\end{array}$ & $\begin{array}{l}\text { The wholeness or integrity of a system; the relationship among a system's constituent elements. } \\
\text { Wear, chemical decomposition, and disassembly all decrease stability. Increasing entropy is } \\
\text { equivalent to decreasing stability. }\end{array}$ \\
\hline 14 & Strength & The extent to which an object can resist changes in response to a force. Resistance to breaking. \\
\hline 15 & $\begin{array}{l}\text { Duration of action by } \\
\text { a moving object }\end{array}$ & $\begin{array}{l}\text { The time that the object can act. Service life. The average time between failures is a measure of the } \\
\text { duration of action. Also called durability. }\end{array}$ \\
\hline 16 & $\begin{array}{l}\text { Duration of action by } \\
\text { a stationary object }\end{array}$ & The same as 15 . \\
\hline 17 & Temperature & $\begin{array}{l}\text { The thermal condition of an object or system. Loosely includes other thermal parameters, such as } \\
\text { heat capacity, that affect the rate of change of temperature. }\end{array}$ \\
\hline 18 & Illumination intensity & $\begin{array}{l}\text { The light flux per unit area. Also, any other illumination characteristics of the system such as } \\
\text { brightness, light quality, etc. }\end{array}$ \\
\hline 19 & $\begin{array}{l}\text { Use of energy by } \\
\text { moving object }\end{array}$ & $\begin{array}{l}\text { The measure of an object's capacity for doing work. In classical mechanics, energy is the product } \\
\text { of force and distance. This includes the use of energy provided by a super-system (such as electrical } \\
\text { energy or heat). The energy required to do a particular job. }\end{array}$ \\
\hline 20 & $\begin{array}{l}\text { Use of energy by a } \\
\text { stationary object }\end{array}$ & The same as 19 . \\
\hline 21 & Power & The rate at which work is performed with respect to time. The rate of use of energy. \\
\hline
\end{tabular}


Table 1

(Continued) Thirty-nine factors in TRIZ in this study.

\begin{tabular}{|c|c|c|}
\hline 22 & ss of energy & $\begin{array}{l}\text { The use of energy that does not contribute to the job being done. See 19. Reducing the loss of } \\
\text { energy sometimes requires different techniques from improving the use of energy, which is why } \\
\text { this is a separate category. }\end{array}$ \\
\hline 23 & nce & $\begin{array}{l}\text { Partial or complete, permanent or temporary loss of some of a system's materials, substances, } \\
\text { parts, or subsystems. }\end{array}$ \\
\hline 24 & Loss of information & $\begin{array}{l}\text { Partial or complete, permanent or temporary loss of data or access to data in or by a system. } \\
\text { Frequently includes sensory data such as aroma, texture, etc. }\end{array}$ \\
\hline 25 & Loss of time & $\begin{array}{l}\text { Time is the duration of an activity. Improving the loss of time means reducing the time taken for } \\
\text { the activity. "Cycle time reduction" is a common term. }\end{array}$ \\
\hline 26 & $\begin{array}{l}\text { Quantity of } \\
\text { substance/ matter }\end{array}$ & $\begin{array}{l}\text { The number or amount of a system's materials, substances, parts, or subsystems that might be } \\
\text { changed fully or partially, permanently or temporarily. }\end{array}$ \\
\hline 27 & liability & predictable ways and conditions. \\
\hline 28 & ement & $\begin{array}{l}\text { The closeness of the measured value to the actual value of a property of a system. Reducing the } \\
\text { error in a measurement increases the accuracy of the measurement. }\end{array}$ \\
\hline 29 & turing & $\begin{array}{l}\text { The extent to which the actual characteristics of the system or object match the specified or } \\
\text { required characteristics. }\end{array}$ \\
\hline 30 & $\begin{array}{l}\text { rnal harm to } \\
\text { ct }\end{array}$ & Susceptibility of a system to externally generated (harmful) effects. \\
\hline 31 & $\begin{array}{l}\text { enerated } \\
\text { factors }\end{array}$ & tem. I hese harmful effects are generated by the object or system as part of its oper \\
\hline 32 & Ease of manufacture & The degree of facility, comfort, or effortlessness in manufacturing or fabricatin \\
\hline 33 & Ease of operation & $\begin{array}{l}\text { Simplicity: A process is not easy if it requires a large number of people, a large number of steps in } \\
\text { the operation, special tools, etc. "Hard" processes have low yield and "easy" processes have high } \\
\text { yield and are easy to do correctly. }\end{array}$ \\
\hline 34 & Ease of repair & $\begin{array}{l}\text { Quality characteristics such as convenience, comfort, simplicity, and time to repair faults, failures, } \\
\text { or defects in a system. }\end{array}$ \\
\hline 35 & ity or & $\begin{array}{l}\text { The extent to which a system/object positively responds to external changes. An adaptable/versatile } \\
\text { system can be used in multiple ways under a variety of circumstances. }\end{array}$ \\
\hline 36 & Devic & $\begin{array}{l}\text { The number and diversity of elements and element interrelationships within a system. The user } \\
\text { may be an element of the system, which increases the complexity. The difficulty of mastering a } \\
\text { system is a measure of its complexity. }\end{array}$ \\
\hline 37 & $\begin{array}{l}\text { Difficulty of detectin } \\
\text { and measuring }\end{array}$ & $\begin{array}{l}\text { Measuring or monitoring systems that are complex, costly, require much time and labor to set up } \\
\text { and use, or have complex relationships between components or components that interfere with } \\
\text { each other all indicate "difficulty of detecting and measuring." An increased cost of measuring to a } \\
\text { satisfactory error is also a sign of the increased difficulty of measuring. }\end{array}$ \\
\hline 38 & Extent of automation & $\begin{array}{l}\text { The extent to which a system or object performs its functions without a human interface. The } \\
\text { lowest level of automation is the use of a manually operated tool. For intermediate levels, humans } \\
\text { program the tool, observe its operation, and interrupt or reprogram as needed. For the highest level, } \\
\text { the machine senses the operation needed, programs itself, and monitors its operations. }\end{array}$ \\
\hline 39 & Productivity & $\begin{array}{l}\text { The number of functions or operations performed by a system per unit time. The time for a unit } \\
\text { function or operation. The output per unit time or the cost per unit output. }\end{array}$ \\
\hline
\end{tabular}

Moving objects: Objects that can easily change position in space, either on their own or as a result of external forces. Stationary objects: Objects that do not change position in space, either on their own or as a result of external forces.

\subsection{TRIZ and game theory}

Liu and Chen used the innovative principles of TRIZ to improve the innovativeness of an engineering system and solve engineering problems when the contradictions in the system cannot be predicted. ${ }^{(5)}$ Their method measured the number of times each innovative principle appeared and ranked them in a table according to how many times they were used. Then, they selected a principle to solve the problems. Even for unknown contradictions in a system, innovative principles could be found for a single engineering parameter. 
Selecting the appropriate principle requires game theory. In a 'game', two or more contenders have to make interdependent decisions if they are rational. Otherwise, the result can be irrational or may even have a Platonic effect. The reward of each contender is determined by each other's decisions. A contender tends to maximize the reward even when the other has the best strategy. As a result, the outcomes of a game may not be rational or efficient. Thus, when contenders make decisions, they consider all possible actions of the other by calculating the probability distribution. As a pay-off function, a reward is given to one contender according to the strategies of the other.

Von Neumann et al. developed game theory by analyzing the interaction between contenders and setting up a mathematical model. ${ }^{(7)}$ Shapley discussed bargaining games, ${ }^{(7)}$ and Gillies and Shapley made great contributions to the development of the core principles of game theory. ${ }^{(8)}$ The prisoner's dilemma and the Nash equilibrium are good analogies for uncooperative game theory. ${ }^{(9)} \mathrm{Wu}$ and Xia explained game theory to illustrate the main concepts of various games and categorized them into four different forms. When the contenders' strategy and pay-off functions are completely known simultaneously, a game is 'static'. When the strategy and functions are known sequentially but continuously, it is 'dynamic'. The type of equilibrium of a game depends on the completeness of the information and whether the game is static or dynamic $^{(10)}$ (Table 2).

We assumed the selection of the quality parameters (outlet temperature, outlet pressure, pressure drop) in a PEMFC to be games having Nash equilibrium in the sub-games with the values of the parameters as contenders. The parameters were selected according to the innovative strategy by TRIZ with a single principle and sequence optimization. ${ }^{(5)}$ Then, the probability of selecting the parameters was calculated in all games to select the strategy with the highest probability. The best strategy for each parameter was obtained by repeating this process.

\subsection{Negotiation in game theory}

Negotiation between the contenders is required for different situations in game theory to solve problems in the economy, politics, and financial analysis. Game theory based on negotiation is regarded as being precise owing to the use of a mathematical model that simplifies complex and interactive phenomena. It also helps to study the strategic behavior of contenders or decision-makers.

A negotiation game has the following characteristics.

(1) Two or more members

Bargaining involves buyers and sellers. Before transactions, buyers are unaware of the supply

and sellers are unaware of the demand. From this starting point, they negotiate an appropriate price.

Table 2

Four main forms of games.

\begin{tabular}{lcc}
\hline & Complete information & Incomplete information \\
\hline Static & Nash equilibrium & Bayesian Nash equilibrium \\
Dynamic & Perfect Nash equilibrium in sub-games & Perfect Nash equilibrium or sequence equilibrium \\
\hline
\end{tabular}


(2) Obvious or potential benefits

Buyers and sellers have their strategies and expectations, and their goals are achieved through negotiation.

(3) Dependence on each other in competition

In a negotiation, a buyer and a seller try to obtain satisfactory results without maximizing their profit. This is because if one pursues the maximum profit, then the other will be dissatisfied. Thus, for their mutual benefit, they need to explore the possibility of compromise. As a result, the negotiation becomes interdependent.

(4) Willingness to work together

Negotiation between a buyer and a seller is to achieve a balanced benefit, which is a basic understanding of them both. Their willingness to solve problems is also essential for the negotiation; only in this way will the negotiation be successful.

In a static game, contenders pursue balanced solutions. However, contenders in a dynamic game bahave independently on the basis of their estimated probability. Therefore, perfect Nash equilibrium in sub-games is adopted to obtain greater reward in the equilibrium through changing the strategy from that in the nonequilibrium. Therefore, a simple strategy is used to simulate the process of a dynamic bargaining game with full information and mutual, conceptual, and strategic agreement. On the basis of this principle of a bargaining game, the multi-quality optimization of the flow parameters of a PEMFC was investigated.

\subsection{Measurement of temperature and pressure}

The parameters such as the temperature, pressure, and flow rate of a PEMFC were measured using an FCED-P200 testing platform manufactured by Asia Pacific Fuel Cell Technologies. The test platform contains devices and electrochemical sensors to measure the temperature and pressure of gases in a fuel cell, and the flow rate was calculated from the measured data and the dimensions of the fuel cell. The test platform was placed in an air-circulating box of $2500 \times 2500 \times 2500 \mathrm{~mm}^{3}(\mathrm{~W} \times \mathrm{D} \times \mathrm{H})$ and operated in the temperature range of $5-40{ }^{\circ} \mathrm{C}$ with a gas supply of nitrogen (>99.99\%), hydrogen (>99.99\%), and air at a pressure of 100 psi in gauge pressure (psig).

\section{Results and Discussion}

\subsection{Application of TRIZ and game theory to PEMFC}

TRIZ is mainly applied to areas such as product and process improvement, elimination of process restrictions, technology forecasting, new product development, patent avoidance, and so forth. ${ }^{(11-14)}$ As TRIZ effectively uses the accumulated knowledge in patents, it offers a creative way to reduce the time and cost of developing or inventing technologies to improve product quality and establish R\&D plans. For example, TRIZ has recently contributed to integrating telemetrics into the wireless communication technology used in self-driving cars. TRIZ affords diverse variables and outcomes in the development, design, and planning of products in which 
there are many conflicting issues. Various analysis and deduction tools in TRIZ enable problems to be confirmed systematically and innovative solutions to be proposed.(7) Game theory also helps resolve the contradictions in economic and engineering processes. Also known as interactive decision theory, game theory provides systematic and strategic interactive analysis tools and methods that allow the best decision in complex and conflicting problems. ${ }^{(15)}$

In this study, the parameters of the flow channel may generate contradictions when improving the performance of a PEMFC. After the contradictory parameters are defined and measured as the input data, TRIZ and game theory are used to create a contradiction matrix table that corresponds to the 40 innovative rules of TRIZ (Table 3 ) and obtain a single-quality optimization strategy for each of the parameters. Then, the optimized strategies help to improve the performance of the PEMFC. The following sections show how the contradicting factors are defined, the contradiction matrix is created, game theory is employed, and the strategy is validated and optimized to improve the PEMFC's performance in this study.

\subsection{Improving and worsening factors}

First, the factors that improve or worsen the system were defined to optimize the parameters for flow control in the PEMFC; these were the outlet temperature, outlet pressure, and pressure drop. Target values of the parameters were obtained to lessen the contradictions when designing the flow control. The principles in the contradiction matrix that suggested ideas and decisions are shown in Tables 4-6.

Table 3

Forty innovative rules of TRIZ. ${ }^{(6)}$

\begin{tabular}{rccc}
\hline No. & Rules & No. & Rules \\
\cline { 3 - 4 } 2 & Segmentation & 21 & Skipping \\
2 & Taking out & 22 & Blessing in disguise \\
3 & Local quality & 23 & Feedback \\
4 & Assymmetry & 24 & Intermediary \\
5 & Merging & 25 & Self-service \\
6 & Universality & 26 & Copying \\
7 & Nested doll & 27 & Cheap short-living objects \\
8 & Anti-weight & 28 & Mechanics substitution \\
9 & Preliminary anti-action & 29 & Pneumatics and hydraulics \\
10 & Preliminary action & 30 & Flexible shells and thin films \\
11 & Beforehand cushioning & 31 & Porous materials \\
12 & Equipotentiality & 32 & Color changes \\
13 & The other way round & 33 & Homogeneity \\
14 & Curvature & 34 & Discarding and recovering \\
15 & Dynamics & 35 & Parameter changes \\
16 & Partial or excessive actions & 36 & Phase transitions \\
17 & Another dimension & 37 & Thermal expansion \\
18 & Mechanical vibration & 38 & Strong oxidants \\
19 & Periodic action & 39 & Inert atmosphere \\
20 & Continuity of useful action & 40 & Composite material \\
\hline
\end{tabular}


Table 4 shows the factors affecting the outlet temperature of the PEMFC. There are three improving factors for lowering the outlet temperature: inlet temperature, inlet pressure, and flow speed. These factors improve the performance of the PEMFC. However, at the same time, they lower the inlet temperature, which causes irregular flow speed, increases the inlet pressure, harms the proton exchange membrane, and increases the flow speed of air and hydrogen. As a result, more energy is needed and the composition of the gases for the electrochemical reaction is inferior to that at a higher temperature.

Table 5 shows the factors affecting outlet pressure in the flow control of the PEMFC. The three improving factors can worsen the performance as they lower the inlet temperature. The lower inlet temperature makes ion transportation difficult, increases the inlet pressure and the flow speed of gases, and harms the proton exchange membrane. These consequences also increase the use of energy and result in an inferior composition of gases for the electrochemical reaction to that at a higher inlet temperature.

Table 6 shows the factors affecting the outlet pressure drop. The three improving factors can worsen the performance by lowering the inlet temperature and increasing the inlet pressure and the flow speed of gases. The effects may result in difficult ion transportation, increased energy use, defects in the proton exchange membrane, and more water production in the flow channel than that at a high inlet temperature.

Table 4

Improving and worsening factors of outlet temperature in flow control of PEMFC.

\begin{tabular}{lll}
\hline Group Improving factors & Worsening factors \\
\hline \multirow{2}{*}{$\begin{array}{l}\text { Change of temperature } \rightarrow \# 17^{*} \text { temperature } \\
\end{array}$} & $\begin{array}{l}\text { higher energy demand } \rightarrow \# 22 \text { loss of energy } \\
\text { uneven distribution of local current } \rightarrow \# 31 \text { object-generated } \\
\text { harmful factors }\end{array}$ \\
\hline $\begin{array}{ll}\text { Change of pressure } \rightarrow \# 11 \text { stress or pressure } \\
\end{array}$ & $\begin{array}{l}\text { haste of energy } \rightarrow \# 22 \text { loss of energy } \\
\text { harmful factors }\end{array}$ \\
\hline & $\begin{array}{l}\text { higher energy demand } \rightarrow \# 22 \text { loss of energy } \\
\text { Change of flow speed } \rightarrow \# 9 \text { speed }\end{array}$ & $\begin{array}{l}\text { harmful factors } \\
\text { power increase } \rightarrow \# 10 \text { force }\end{array}$ \\
\hline
\end{tabular}

*Numbers correspond to the factors in Table 1.

Table 5

Improving and worsening factors of outlet pressure in flow control of PEMFC.

\begin{tabular}{lll}
\hline Group Improving factors & Worsening factors \\
\hline 1 & Change of temperature $\rightarrow \# 17$ temperature & $\begin{array}{l}\text { ion transport is difficult } \rightarrow \# 31 \text { object-generated harmful } \\
\text { factors }\end{array}$ \\
\hline $2 \quad$ Change of pressure $\rightarrow \# 11$ stress or pressure & $\begin{array}{l}\text { higher energy demand } \rightarrow \# 22 \text { loss of energy } \\
\text { harm to proton exchange membrane } \rightarrow \# 31 \text { object-generated } \\
\text { harmful factors }\end{array}$ \\
\hline \multirow{3}{*}{ Change of flow speed $\rightarrow \# 9$ speed } & $\begin{array}{l}\text { higher energy demand } \rightarrow \# 22 \text { loss of energy } \\
\text { reaction gas is inferior for reaction } \rightarrow \# 31 \text { object-generated } \\
\text { harmful factors }\end{array}$ \\
\cline { 3 - 4 } & power increase $\rightarrow \# 10$ force \\
\hline
\end{tabular}


Table 6

Improving and worsening factors of outlet pressure drop in flow control of PEFMC.

\begin{tabular}{lll}
\hline Group Improving factors & Worsening factors \\
\hline 1 & Change of temperature $\rightarrow \# 17$ temperature & $\begin{array}{l}\text { higher energy demand } \rightarrow \# 22 \text { loss of energy } \\
\text { uneven distribution of local current } \rightarrow \# 31 \text { object-generated } \\
\text { harmful factors }\end{array}$ \\
\hline \multirow{2}{*}{$\begin{array}{ll}\text { Change of pressure } \rightarrow \# 11 \text { stress or pressure } \\
\end{array}$} & $\begin{array}{l}\text { higher energy demand } \rightarrow \# 22 \text { loss of energy } \\
\text { harm to proton exchange membrane } \rightarrow \# 31 \text { object-generated } \\
\text { harmful factors }\end{array}$ \\
\hline Change of flow speed $\rightarrow \# 9$ speed & $\begin{array}{l}\text { harm to proton exchange membrane } \rightarrow \# 9 \text { speed } \\
\text { harmful factors }\end{array}$ \\
\hline
\end{tabular}

\subsection{Contradiction matrix}

On the basis of the above results, the contradictory factors of the outlet temperature, outlet pressure, and pressure drop were defined for the inlet temperature, inlet pressure, and flow speed (Tables 7-9). Each cell indicates the innovative principles for improving the flow control of the PEMFC.

Table 7

Contradiction matrix of outlet temperature in flow control of PEFMC.

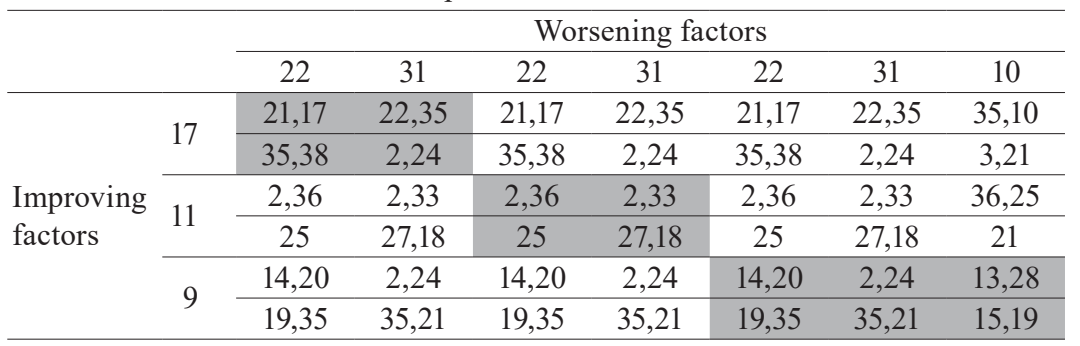

Numbers in cells correspond to the factors in Table 1.

Table 8

Contradiction matrix of outlet pressure in flow control of PEFMC.

\begin{tabular}{|c|c|c|c|c|c|c|c|}
\hline & \multicolumn{6}{|c|}{ Worsening factors } \\
\hline & & 22 & 31 & 22 & 31 & 9 & 31 \\
\hline \multirow{6}{*}{$\begin{array}{l}\text { Improving } \\
\text { factors }\end{array}$} & \multirow{2}{*}{17} & 21,17 & 22,35 & 21,17 & 22,35 & 2,28 & 22,35 \\
\hline & & 35,38 & 2,24 & 35,38 & 2,24 & 36,30 & 2,24 \\
\hline & \multirow{2}{*}{11} & 2,36 & 2,33 & 2,36 & 2,33 & 6,35 & 2,33 \\
\hline & & 25 & 27,18 & 25 & 27,18 & 36 & 27,18 \\
\hline & \multirow{2}{*}{9} & 14,20 & 2,24 & 14,20 & 2,24 & - & 2,24 \\
\hline & & 19,35 & 35,21 & 19,35 & 35,21 & - & 35,21 \\
\hline
\end{tabular}


Table 9

Contradiction matrix of oil pressure drop in flow control of PEFMC.

\begin{tabular}{|c|c|c|c|c|c|c|c|}
\hline & \multicolumn{6}{|c|}{ Worsening factors } \\
\hline & & 31 & 22 & 31 & 22 & 31 & 10 \\
\hline \multirow{6}{*}{$\begin{array}{l}\text { Improving } \\
\text { factors }\end{array}$} & \multirow{2}{*}{17} & 22,35 & 21,17 & 22,35 & 21,17 & 22,35 & 35,10 \\
\hline & & 2,24 & 35,38 & 2,24 & 35,38 & 2,24 & 3,21 \\
\hline & \multirow{2}{*}{11} & 2,33 & 2,36 & 2,33 & 2,36 & 2,33 & 36,25 \\
\hline & & 27,18 & 25 & 27,18 & 25 & 27,18 & 21 \\
\hline & \multirow{2}{*}{9} & 2,24 & 14,20 & 2,24 & 14,20 & 2,24 & 13,28 \\
\hline & & 35,21 & 19,35 & 35,21 & 19,35 & 35,21 & 15,19 \\
\hline
\end{tabular}

\subsection{Results of game theory}

On the basis of game theory, the principles with high weights are regarded as having a high probability of enhancing the performance of the PEMFC. The weight of a principle is defined as the number of appearances of the strategy in the matrix cells. The weights and ranks are shown in Tables 10-12. The control strategies for the inlet temperature, inlet pressure, and flow rate to enhance the performance of the PEMFC are listed in Tables 13-15.

Table 10

Weights and ranks of strategies for outlet temperature in flow control of PEMFC.

\begin{tabular}{|c|c|c|c|c|}
\hline Weight & Probability of success & Rank & Appearances & Principles \\
\hline 7 & \multirow{2}{*}{ High } & A & More than 19 times & - \\
\hline 6 & & $\mathrm{~B}$ & $16-18$ & - \\
\hline 5 & \multirow{4}{*}{ Middle } & $\mathrm{C}$ & $13-15$ & 35: Parameter changes \\
\hline 4 & & $\mathrm{D}$ & $10-12$ & 2: Taking out \\
\hline 3 & & $\mathrm{E}$ & $7-9$ & 21: Skipping \\
\hline 2 & & $\mathrm{~F}$ & $4-6$ & $\begin{array}{l}\text { 19: Periodic action } \\
\text { 24: Intermediary } \\
\text { 36: Phase transitions }\end{array}$ \\
\hline 1 & Low & G & $1-3$ & $3,10,13,14,15,17,18,20,22,25,27,28,33,38$ \\
\hline
\end{tabular}

Table 11

Weights and ranks of strategies of outlet pressure in flow control of PEMFC.

\begin{tabular}{|c|c|c|c|c|}
\hline Weight & Probability of success & Rank & Appearances & Principles \\
\hline 7 & \multirow{2}{*}{ High } & $\mathrm{A}$ & More than 19 times & - \\
\hline 6 & & B & $16-18$ & - \\
\hline 5 & \multirow{4}{*}{ Middle } & $\mathrm{C}$ & $13-15$ & - \\
\hline 4 & & $\mathrm{D}$ & $10-12$ & $\begin{array}{c}\text { 2: Taking out } \\
\text { 35: Parameter changes }\end{array}$ \\
\hline 3 & & $\mathrm{E}$ & $7-9$ & - \\
\hline 2 & & $\mathrm{~F}$ & $4-6$ & $\begin{array}{c}\text { 21: Skipping } \\
\text { 24: Intermediary } \\
\text { 36: Phase transitions }\end{array}$ \\
\hline 1 & Low & G & $1-3$ & $6,14,17,18,19,20,22,25,27,28,30,33,38$ \\
\hline
\end{tabular}


Table 12

Weights and ranks of strategies of pressure drop in flow control of PEMFC.

\begin{tabular}{|c|c|c|c|c|}
\hline Weight & Probability of success & Rank & Appearances & Principles \\
\hline \multirow{3}{*}{7} & \multirow{4}{*}{ High } & \multirow{3}{*}{ A } & \multirow{3}{*}{ More than 19 times } & - \\
\hline & & & & - \\
\hline & & & & - \\
\hline 6 & & B & $16-18$ & - \\
\hline 5 & \multirow{4}{*}{ Middle } & $\mathrm{C}$ & $13-15$ & - \\
\hline 4 & & $\mathrm{D}$ & $10-12$ & $\begin{array}{c}\text { 2: Taking out } \\
\text { 35: Parameter changes }\end{array}$ \\
\hline 3 & & $\mathrm{E}$ & $7-9$ & 21: Skipping \\
\hline 2 & & $\mathrm{~F}$ & $4-6$ & 24: Intermediary \\
\hline 1 & Low & G & $1-3$ & $3,10,13,14,15,17,18,20,22,25,27,28,33,38,36,19$ \\
\hline
\end{tabular}

Table 13

Weights of outlet temperature.

\begin{tabular}{lcc}
\hline Factor & Selected strategy & Weight \\
\hline Inlet temperature & 35: Parameter changes & 5 \\
Inlet pressure & 2: Taking out & 4 \\
Flow rate & 35: Parameter changes & 5 \\
\hline
\end{tabular}

Table 14

Weights of outlet pressure.

\begin{tabular}{lcc}
\hline Factor & Most selected strategy & Weight \\
\hline Inlet temperature & 35: Parameter changes & 4 \\
Inlet pressure & 2: Taking out & 4 \\
Flow rate & 35: Parameter changes & 4 \\
\hline
\end{tabular}

Table 15

Weights of pressure drop.

\begin{tabular}{lcc}
\hline Factor & Most selected strategy & Weight \\
\hline Inlet temperature & 35: Parameter changes & 4 \\
Inlet pressure & 2: Taking out & 4 \\
Flow rate & 35: Parameter changes & 5 \\
\hline
\end{tabular}

\subsection{Validation of strategies}

From the contradiction matrix, the following strategies for the flow control of the PEMFC were selected.

(1) To optimize the outlet temperature of the flow channel of the PEMFC, the inlet temperature, inlet pressure, and flow rate need to increase.

(2) To optimize the outlet pressure, the inlet temperature and inlet pressure need to increase but the flow rate needs to decrease.

(3) To optimize the pressure drop, the inlet temperature needs to decrease but the inlet pressure and flow rate need to increase. 
Experiments based on the innovation strategies were carried out to validate the effect of changing the inlet temperature, inlet pressure, and flow rate on the outlet temperature, outlet pressure, and pressure drop. The outlet temperature increased by $16.7 \%$ by increasing the inlet temperature from 60 to $70{ }^{\circ} \mathrm{C}$. The outlet pressure increased by 81.5 and $10.9 \%$ by increasing the inlet pressure from 3 to 5 bar and decreasing the flow rate from 1.5 to $1 \mathrm{~m} / \mathrm{s}$, respectively. The pressure dropped by $65.0 \%$ by increasing the flow rate from 1.5 to $2 \mathrm{~m} / \mathrm{s}$. The results of the COMSOL simulation proved that the strategies selected with TRIZ and game theory produced better data than those without them (Tables 16-18).

Table 16

Optimized outlet temperature with increases in inlet temperature (A1), inlet pressure (A2), and flow rate (A3).

\begin{tabular}{|c|c|c|c|c|c|}
\hline \multirow{3}{*}{ Experiment } & Inlet temperature $\left({ }^{\circ} \mathrm{C}\right)$ & Inlet pressure (bar) & Flow rate $(\mathrm{m} / \mathrm{s})$ & Outlet temperature $\left({ }^{\circ} \mathrm{C}\right)$ & \multirow{3}{*}{$\begin{array}{c}\text { Temperature } \\
\text { difference (\%) }\end{array}$} \\
\hline & \multicolumn{4}{|c|}{ (original values) } & \\
\hline & 60 & 3 & 1.5 & 59.99957 & \\
\hline A1 & 70 & 3 & 1.5 & 69.99933 & 16.66638611 \\
\hline $\mathrm{A} 2$ & 60 & 5 & 1.5 & 59.99962 & 0.00008333 \\
\hline A3 & 60 & 3 & 2 & 59.99958 & 0.00001667 \\
\hline
\end{tabular}

Table 17

Optimized outlet pressure with increases in inlet temperature (B1) and inlet pressure (B2) and decrease in flow rate (B3).

\begin{tabular}{|c|c|c|c|c|c|}
\hline \multirow{3}{*}{ Experiment } & Inlet temperature $\left({ }^{\circ} \mathrm{C}\right)$ & Inlet pressure (bar) & Flow rate $(\mathrm{m} / \mathrm{s})$ & Outlet pressure (bar) & \multirow{3}{*}{$\begin{array}{c}\text { Pressure } \\
\text { difference (\%) }\end{array}$} \\
\hline & \multicolumn{4}{|c|}{ (original values) } & \\
\hline & 60 & 3 & 1.5 & 2.454118 & \\
\hline$\overline{\mathrm{B} 1}$ & 70 & 3 & 1.5 & 2.454137 & 0.00077421 \\
\hline B2 & 60 & 5 & 1.5 & 4.454017 & 81.49155827 \\
\hline B3 & 60 & 3 & 1 & 2.722468 & 10.93468203 \\
\hline
\end{tabular}

Table 18

Optimized pressure drop with decrease in inlet temperature $(\mathrm{C} 1)$ and increases in inlet pressure $(\mathrm{C} 2)$ and flow rate (C3).

\begin{tabular}{|c|c|c|c|c|c|}
\hline \multirow{3}{*}{ Experiment } & Inlet temperature $\left({ }^{\circ} \mathrm{C}\right)$ & Inlet pressure (bar) & Flow rate $(\mathrm{m} / \mathrm{s})$ & Pressure drop (bar) & \multirow{3}{*}{$\begin{array}{l}\text { Pressure drop } \\
\text { difference }(\%)\end{array}$} \\
\hline & \multicolumn{4}{|c|}{ (original values) } & \\
\hline & 60 & 3 & 1.5 & 0.545882 & \\
\hline $\mathrm{C} 1$ & 50 & 3 & 1.5 & 0.545894 & 0.002198229 \\
\hline $\mathrm{C} 2$ & 60 & 5 & 1.5 & 0.545983 & 0.018502167 \\
\hline $\mathrm{C} 3$ & 60 & 3 & 2 & 0.900840 & 65.02467566 \\
\hline
\end{tabular}




\subsection{Optimizing strategy}

A schematic diagram of optimizing the strategy in this study is shown in Fig. 1. When contender A bids 2.0, 1.8, and 1.6, contender B needs to decide which to accept. If contender B chooses 2.0, it bids back 1.0, 1.2, and 1.4 to contender A. Contender A always wants the maximum reward. If contender B is not satisfied with contender A's bid, contender A must choose less reward. In Fig. 1, contender A chooses 1.4 from contender B's bid and bids back 2.0, 1.8, and 1.6 again. Then, contender B chooses 1.8, and contender A selects 1.2. After repeating this process until the negotiation stops, contenders $\mathrm{A}$ and $\mathrm{B}$ choose 1.6 and 1.0 as the final reward, respectively. In this game, contender B is the weaker contender who concedes less benefit, while contender $\mathrm{A}$ is the stronger one with less loss.

Table 19 shows the simulation results of 27 different scenarios with changes (increase, unchanged, decrease) in the inlet temperature, inlet pressure, and flow rate, which are input as contenders in the bargaining game.

The scenario with the best result was obtained for the inlet temperature of $70{ }^{\circ} \mathrm{C}$, inlet pressure of $5 \mathrm{bar}$, and flow rate of $1.6 \mathrm{~m} / \mathrm{s}$. These parameters yielded an outlet temperature of $69.99942{ }^{\circ} \mathrm{C}$, outlet pressure of 4.39008 bar, and pressure drop of 0.609919 bar. The values were lower than those found in Tables 16-18 and superior to those used in a practical application (Table 20).

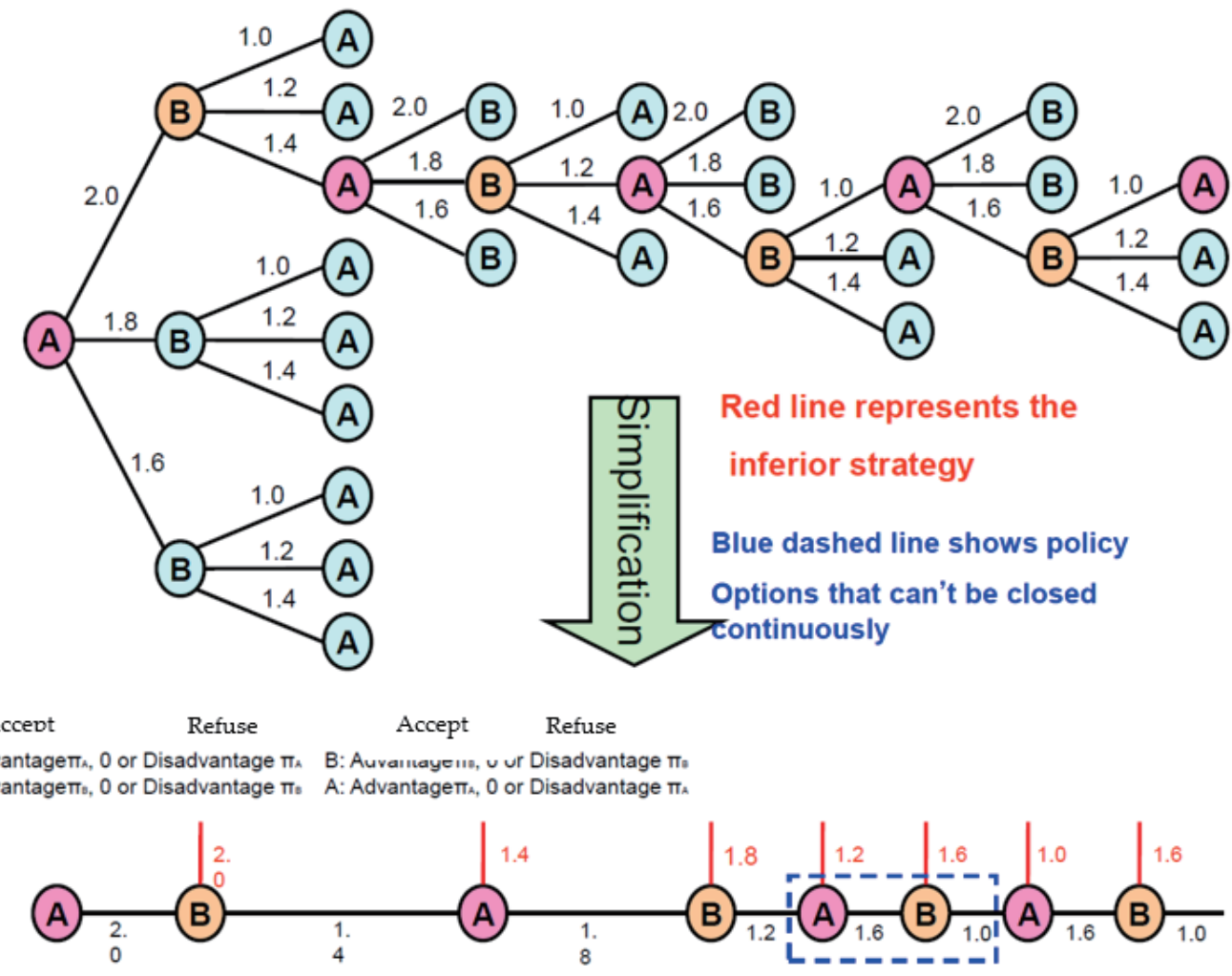

Fig. 1. (Color online) Experimental setup in this study. 
Table 19

Simulation results of optimizing parameters.

\begin{tabular}{|c|c|c|c|c|c|c|}
\hline Scenarios & Inlet temperature & Inlet pressure & Flow rate & $\begin{array}{c}\text { Outlet } \\
\text { temperature }\left({ }^{\circ} \mathrm{C}\right)\end{array}$ & $\begin{array}{l}\text { Outlet pressure } \\
\text { (bar) }\end{array}$ & $\begin{array}{l}\text { Pressure drop } \\
\text { (bar) }\end{array}$ \\
\hline 1 & Decrease & Decrease & Decrease & 48.98598 & 0.722437 & 0.277563 \\
\hline 2 & Decrease & Decrease & Unchanged & 49.98657 & 0.454011 & 0.545989 \\
\hline 3 & Decrease & Decrease & Increase & 49.98657 & 0.454011 & 0.900846 \\
\hline 4 & Decrease & Unchanged & Decrease & 49.98762 & 2.722464 & 0.277536 \\
\hline 5 & Decrease & Unchanged & Unchanged & 49.98987 & 2.454106 & 0.545894 \\
\hline 6 & Decrease & Unchanged & Increase & 49.98987 & 2.099030 & 0.900970 \\
\hline 7 & Decrease & Increase & Decrease & 49.99084 & 4.722439 & 0.277561 \\
\hline 8 & Decrease & Increase & Unchanged & 49.99411 & 4.454003 & 0.545997 \\
\hline 9 & Decrease & Increase & Increase & 49.99971 & 4.099110 & 0.900890 \\
\hline 10 & Unchanged & Decrease & Decrease & 59.99118 & 0.722457 & 0.277543 \\
\hline 11 & Unchanged & Decrease & Unchanged & 59.99311 & 0.454054 & 0.545946 \\
\hline 12 & Unchanged & Decrease & Increase & 59.99428 & 0.099173 & 0.900827 \\
\hline 13 & Unchanged & Unchanged & Decrease & 59.99375 & 2.722496 & 0.277504 \\
\hline 14 & Unchanged & Unchanged & Unchanged & 59.99482 & 2.454117 & 0.545883 \\
\hline 15 & Unchanged & Unchanged & Increase & 59.99558 & 2.099160 & 0.900840 \\
\hline 16 & Unchanged & Increase & Decrease & 59.99626 & 4.722445 & 0.277555 \\
\hline 17 & Unchanged & Increase & Unchanged & 59.99713 & 4.454016 & 0.545984 \\
\hline 18 & Unchanged & Increase & Increase & 59.99802 & 4.099170 & 0.900830 \\
\hline 19 & Increase & Decrease & Decrease & 69.98970 & 0.722474 & 0.277526 \\
\hline 20 & Increase & Decrease & Unchanged & 69.99228 & 0.454136 & 0.545864 \\
\hline 21 & Increase & Decrease & Increase & 69.99401 & 0.099240 & 0.900760 \\
\hline 22 & Increase & Unchanged & Decrease & 69.99537 & 2.722474 & 0.277526 \\
\hline 23 & Increase & Unchanged & Unchanged & 69.99685 & 2.454133 & 0.545867 \\
\hline 24 & Increase & Unchanged & Increase & 69.99735 & 2.099240 & 0.900760 \\
\hline 25 & Increase & Increase & Decrease & 69.99872 & 4.722481 & 0.277519 \\
\hline 26 & Increase & Increase & Unchanged & 69.99941 & 4.454021 & 0.545979 \\
\hline 27 & Increase & Increase & Increase & 69.99948 & 4.099230 & 0.900700 \\
\hline
\end{tabular}

Table 20

Comparison of multi-quality optimal scheme and median value.

\begin{tabular}{|c|c|c|c|c|c|}
\hline & $\begin{array}{l}\text { Inlet temperature } \\
\left({ }^{\circ} \mathrm{C}\right)\end{array}$ & $\begin{array}{l}\text { Inlet pressure } \\
\text { (bar) }\end{array}$ & Flow rate $(\mathrm{m} / \mathrm{s})$ & Compa & son \\
\hline \multirow{3}{*}{$\begin{array}{l}\text { Parameters of } \\
\text { this study }\end{array}$} & \multirow{3}{*}{ 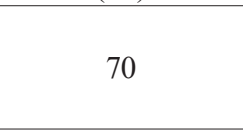 } & \multirow{3}{*}{5} & \multirow{3}{*}{1.6} & Outlet temperature & $69.99942\left({ }^{\circ} \mathrm{C}\right)$ \\
\hline & & & & Outlet pressure & 4.390081 (bar) \\
\hline & & & & Pressure drop & $0.609919(\mathrm{~m} / \mathrm{s})$ \\
\hline \multirow{3}{*}{$\begin{array}{l}\text { Median value } \\
\text { in practical } \\
\text { applicable range }\end{array}$} & \multirow{3}{*}{60} & \multirow{3}{*}{3} & \multirow{3}{*}{1.5} & Outlet temperature & $59.99482\left({ }^{\circ} \mathrm{C}\right)$ \\
\hline & & & & Outlet pressure & 2.454117 (bar) \\
\hline & & & & Pressure drop & $0.545883(\mathrm{~m} / \mathrm{s})$ \\
\hline
\end{tabular}

\section{Conclusions}

We proposed optimizing the flow control of a PEMFC with TRIZ via the outlet temperature, outlet pressure, and pressure drop. There are contradictions in the optimization as these factors have either positive or negative effects on the performance of a PEMFC depending on their combination. Thus, game theory was applied to achieve multi-quality optimization. For the flow 
control of the three parameters (outlet temperature, outlet pressure, and pressure drop), the inlet temperature, inlet pressure, and flow rate were selected as the important factors. The results indicated that the outlet temperature, outlet pressure, and pressure drop increased by $16.67,78.8$, and $11.73 \%$, respectively, upon optimization. It turned out that simulating and predicting the parameters for flow control were effective for reducing the simulation time and the amount of decision-making. This study proves that TRIZ allows a single-quality strategy and that game theory with TRIZ contributes to multi-quality optimization. The combined method provides an innovative and reliable method for establishing an appropriate strategy for developing and manufacturing devices with many factors and parameters considered. In particular, the results of this study provide a reference for designing flow control and for developing and producing PEMFCs with improved performance.

\section{References}

1 G. Altshuller: To Find an Idea, http://www.altshuller.ru/world/eng (accessed October 2020).

2 N. León-Rovira and H. Aguayo: A new Model of the Conceptual Design Process using QFD/FA/TRIZ, https:// triz-journal.com/new-model-conceptual-design-process-using-qfdfatriz/ (accessed October 2020).

3 P. R. Apte and D. L. Mann: Taguchi and TRIZ: Comparisons and Opportunities, https://triz-journal.com/ taguchi-triz-comparisons-opportunities/ (accessed October 2020).

4 C. Liu and J. L. Chen: A TRIZ Inventive Design Method without Contradiction Information, https://trizjournal.com/triz-inventive-design-method-without-contradiction-information/ (accessed October 2020).

5 Z. C. Liu: TRIZ Green Innovative Design Method (Green Design Newsletter, 2003) pp. 15-31. https://www. airitilibrary.com/Publication/alDetailedMesh?docid=U0026-0812200910350099/ (accessed June 2020).

6 E. Domb: https://riz-journal.com/39-features-altshullers-contradiction-matrix/ (accessed October 2020).

7 L. S. Shapley: A Value for n-Person Games, Contributions to the Theory of Games Volume II, H. W. Kuhn and A. W. Tucker Eds. (Princeton University Press, Princeton, 1953) pp. 207-318.

8 D. Gillies: Some theorems on n-person games, Ph.D. thesis (Princeton University, 1953). https://ci.nii.ac.jp/ naid/10017506568/ (accessed September 2020).

9 D. M. Kreps: Game Theory and Economic Modeling, D. M. Kreps, Ed. (Clarendon Press, Oxford, 1992) pp. 91-132.

10 H. M. Wu and Z. Xia: Game Master-all-round Strategy and Application (Times Publishing, Taiwan, 2003) https://scholar.google.com.tw/scholar?cluster $=9669767295693856984 \& \mathrm{hl}=$ zh-TW\&as_sdt $=2005 \&$ sciodt $=0,5$ (accessed July 2020).

11 R. Srinivasan and A. Kraslawsk: Chem. Eng. Process. 45 (2006) 507. https://doi.org/10.1016/j.cep.2005.11.009

12 H. T. Loh, C. He, and L. Shen: World Pat. Inf. 28 (2006) 6. https://doi.org/10.1016/j.wpi.2005.07.007

13 V. Goepp, F. Kiefer, and F. Geiskopf: COMPUT. IND. 57 (2006) 189. https://doi.org/10.1016/j. compind.2005.09.001

14 G. C. Robles, S. Negny, and J. M. Le Lann: Chem. Eng. Process. 48 (2009) 239. https://doi.org/10.1016/j. cep.2008.03.016

15 D. M. Ramsey: Eur. J. Oper. Res. 188 (2008) 586. https://doi.org/10.1016/j.ejor.2007.05.031 